\title{
Amino acid and ureide transport in the xylem of symbiotic soybean plants during short-term flooding of the root system in the presence of different sources of nitrogen
}

\author{
André Luís Thomas ${ }^{*}$ and Ladaslav Sodek ${ }^{2}$
}

\begin{abstract}
${ }^{1}$ Departamento de Plantas de Lavoura, Faculdade de Agronomia, Universidade Federal do Rio Grande do Sul, CP 15100, CEP 90001970, Porto Alegre, RS, Brazil; ${ }^{2}$ Departamento de Fisiologia Vegetal, Instituto de Biologia, Universidade Estadual de Campinas, CP 6109, 13083-970, Campinas, SP, Brazil; *Corresponding author: thomaspl@ufrgs.br
\end{abstract}

Received: 23/03/2006, Accepted: 26/06/2006

The transport of organic $\mathrm{N}$ compounds to the shoot in the xylem sap of nodulated soybean plants was investigated in an attempt to better understand the changes in $\mathrm{N}$ metabolism under root hypoxia (first 5 days of flooding), with different sources of $\mathrm{N}$ in the medium. $\mathrm{NO}_{3}{ }^{-}$is beneficial for tolerance of plants to waterlogging, whereas other $\mathrm{N}$ sources such as $\mathrm{NH}_{4}^{+}$and $\mathrm{NH}_{4} \mathrm{NO}_{3}$, are not. Nevertheless, in the presence of $\mathrm{NH}_{4}{ }^{+}$high levels of amino acids were transported in the xylem, consistent with its assimilation. Some increase in the transport of amino acids was also seen with $\mathrm{NO}_{3}{ }^{-}$nutrition during waterlogging, but not with $\mathrm{N}$-free medium. Ureide transport in the xylem was severely reduced during waterlogging, consistent with impaired $\mathrm{N}_{2}$ fixation under these conditions. The relative proportions of some amino acids in the xylem showed dramatic changes during treatment. Alanine increased tremendously under root hypoxia, especially with $\mathrm{NH}_{4}^{+}$as $\mathrm{N}$ source, where it reached near 70 $\%$ of the total amino acids present. Aspartic acid, on the other hand, dropped to very low levels and was inversely related to alanine levels, consistent with this amino acid being the immediate source of $\mathrm{N}$ for alanine synthesis. Glutamine levels also fell to a larger or lesser extent, depending on the $\mathrm{N}$ source present. The changes in asparagine, one of the prominent amino acids of the xylem sap, were most outstanding in the treatment with $\mathrm{NO}_{3}{ }^{-}$, where they showed a large increase, characteristic of plants switching from dependence on $\mathrm{N}_{2}$ fixation to $\mathrm{NO}_{3}{ }^{-}$assimilation. The data indicate that the lesser effectiveness of $\mathrm{NH}_{4}{ }^{+}$during waterlogging, in contrast to $\mathrm{NO}_{3}{ }^{-}$, involves restricted amino acids metabolism, and may result from energy metabolism being directed towards $\mathrm{NH}_{4}^{+}$detoxification.

Key words: Glycine max, alanine, hypoxia, $\mathrm{N}$ metabolism.

Transporte de aminoácidos e ureídeos no xilema de plantas de soja simbióticas sob curto período de alagamento do sistema radicular com diferentes fontes de nitrogênio: $O$ transporte de compostos nitrogenados orgânicos à parte aérea de plantas de soja, através da seiva do xilema, foi investigado para melhor entender as mudanças no metabolismo do sistema radicular sob hipoxia (primeiros 5 dias de alagamento) e com diferentes fontes de $\mathrm{N}$ no meio. $\mathrm{O} \mathrm{NO}_{3}$ - é benéfico à tolerância das plantas ao alagamento, enquanto que outras fontes de $\mathrm{N}$, como o $\mathrm{NH}_{4} \mathrm{NO}_{3}$ e o $\mathrm{NH}_{4}$, não são. Contudo, na presença de $\mathrm{NH}_{4}{ }^{+}$elevados níveis de aminoácidos foram transportados no xilema, demonstrando sua assimilação. Algum aumento no transporte de aminoácidos também ocorreu com a presença de $\mathrm{NO}_{3}$ - durante o alagamento, mas não na ausência de $\mathrm{N}$ no meio. $\mathrm{O}$ transporte de ureídeos no xilema foi severamente reduzido durante o alagamento, demonstrando a inibição da fixação de $\mathrm{N}_{2}$ nessa condição. As proporções relativas de alguns aminoácidos no xilema demonstraram mudanças drásticas durante os tratamentos. Alanina aumentou acentuadamente com o sistema radicular sob hipoxia, especialmente com $\mathrm{NH}_{4}{ }^{+}$como fonte de $\mathrm{N}$, quando ela atingiu aproximadamente $70 \%$ dos aminoácidos presentes. Por outro lado, o ácido aspártico atingiu níveis muito baixos que foram inversos aos níveis de alanina, indicando ser ele a fonte imediata de $\mathrm{N}$ à síntese de alanina. Os níveis de glutamina também diminuíram numa maior ou menor extensão, dependendo da fonte de $\mathrm{N}$ presente. As mudanças na asparagina, um dos aminoácidos mais proeminentes na seiva do xilema, foram mais salientes no tratamento com $\mathrm{NO}_{3}{ }^{-}$, onde elas demonstraram um grande incremento, característica de plantas que trocam sua dependência de fonte de $\mathrm{N}$ da fixação de $\mathrm{N}_{2}$ para assimilação de $\mathrm{NO}_{3}{ }^{-}$. Os dados indicam que a menor eficiência do $\mathrm{NH}_{4}{ }^{+}$durante o alagamento, em contraste com o $\mathrm{NO}_{3}{ }_{3}^{-}$, envolve metabolismo restrito de aminoácidos que pode ser resultante do dispêndio de energia para a destoxificação de $\mathrm{NH}_{4}^{+}$.

Palavras-chave: Glycine max, alanina, hipoxia, metabolismo de N. 


\section{INTRODUCTION}

Plants may acquire $\mathrm{N}$ in mineral form from the soil or, in the case of symbiotic legumes, by fixation of atmospheric $\mathrm{N}_{2}$, a process that requires $\mathrm{O}_{2}$ to meet the energy demands (Blumenthal et al., 1997). However, when hydromorphic soils become flooded or carry excessive humidity the availability of $\mathrm{O}_{2}$ diminishes, in view of the diffusion rate being 10,000 times less than in air and the dissolved concentration in water being some 30 times lower than in air (Armstrong et al., 1994). Total depletion of dissolved $\mathrm{O}_{2}$ is possible within $24 \mathrm{~h}$ of flooding, due to its consumption by micro-organisms and plants (Armstrong et al., 1994, Drew et al., 2000; Liesack et al. 2000). Flooding of the soil can lead to an accumulation of $\mathrm{NH}_{4}^{+}$, since the absence of $\mathrm{O}_{2}$ interrupts nitrification of $\mathrm{NH}_{4}{ }^{+}$, while $\mathrm{NO}_{3}{ }^{-}$is the first oxidized compound in the soil to be utilized by anaerobic micro-organisms (Marschner, 1995; Sousa et al., 2000). The low availability or absence of $\mathrm{O}_{2}$ induces anaerobic respiration in the root system of soybean (Sousa and Sodek, 2002b) resulting in alterations of amino acids and ureides in the xylem sap (Puiatti and Sodek, 1999; Sousa and Sodek, 2003; Amarante and Sodek, 2006). The transport of nitrogenous compounds in the xylem sap can reflect dynamic aspects of $\mathrm{N}$ metabolism in the root system and thereby provide useful information on the changes brought about by stress (Sousa and Sodek, 2003; Lima and Sodek, 2003; Thomas et al., 2005). In the xylem sap of the soybean plant, where the root system is under hypoxia, there is a large relative increase in alanine with smaller increases in Gaba and serine. The increase in alanine is the result of changes in metabolism mainly in the roots and to a lesser extent in the nodules (Puiatti and Sodek, 1999; Sousa and Sodek, 2003; Amarante and Sodek, 2006). The levels of glutamine and ureides diminish sharply in the xylem sap on flooding (Puiatti and Sodek, 1999; Amarante and Sodek, 2006), indicating impaired $\mathrm{N}_{2}$ fixation.

The presence of $\mathrm{NO}_{3}^{-}$during flooding increases tolerance to this stress, but little is known of the underlying mechanisms (Malavolta, 1954; Trought and Drew, 1981; Prioul and Guyot, 1985, Bacanamwo and Purcell, 1999a,b; Kaiser and Huber, 2001; Magalhães et al., 2002; Sousa and Sodek, 2002a). Tolerance to flooding can arise in the long-term with the formation of aerenchyma, an important morphological adaptation resulting in increased availability of oxygen to submerged roots (Drew et al, 2000). However, in soybean at least, nitrate must exert its beneficial effect on flooding tolerance by other mechanisms since it was found to diminish the amount of aerenchyma formed
(Bacanamwo and Purcell, 1999a). On the other hand, the effect of $\mathrm{NH}_{4}^{+}$(the predominant form of $\mathrm{N}$ in flooded soils) on the metabolism and development of legumes under hypoxia has received little attention, although it is known that the exclusive feeding of $\mathrm{NH}_{4}^{+}$, even under aerobic conditions, can be harmful to many plant species (Howitt and Udvardi, 2000; Wirén et al., 2000; Brito et al., 2001). In a previous study (Thomas and Sodek, 2005), it was shown that tolerance of soybean to flooding was enhanced by $\mathrm{NO}_{3}{ }^{-}$ but not by $\mathrm{NH}_{4}{ }^{+}$. Here, in a parallel study, we present data on the transport of nitrogenous compounds to the shoot (via xylem) under hypoxic conditions that prevail in the roots during the initial period of flooding, before the appearance of aerenchyma, in an attempt to understand the contrasting response of flooded soybean to external mineral $\mathrm{N}$ sources.

\section{MATERIAL AND METHODS}

Soybean plants (Glycine max L. Merr., cv. FT-Abyara), inoculated on sowing with Bradyrhizobium elkanii, strain SEMIA 5019, were grown in a greenhouse under natural light and temperature conditions (average maximum and minimum temperatures of $38^{\circ} \mathrm{C}$ and $19^{\circ} \mathrm{C}$, respectively. Plants were grown in $2 \mathrm{~L}$ plastic pots, with 2 plants per pot, containing vermiculite as substrate and supplied with 200 $\mathrm{mL}$ of $\mathrm{N}$-free nutrient solution (Hoagland and Arnon, 1950) up to the V6-7 growth stage (plants in the vegetative stage with 5 or 6 fully-expanded trifoliolate leaves (Costa and Marchezan, 1982). At this stage the pots were placed inside $3 \mathrm{~L}$ non-perforated pots and the root system flooded with $\mathrm{N}$-free nutrient solution at $1 / 3$ strength. According to the treatment, $5 \mathrm{mM}$ of $\mathrm{N}$ was added in the form of $\mathrm{NO}_{3}{ }^{-}, \mathrm{NH}_{4}{ }^{+}$ or $\mathrm{NH}_{4} \mathrm{NO}_{3}$. The $\mathrm{N}$ concentration at $5 \mathrm{mM}$ is equivalent to that of $\mathrm{N}$ in Hoagland and Arnon's (1950) complete solution at $1 / 3$ strength. $\mathrm{KNO}_{3}$ was used as a source of $\mathrm{NO}_{3}{ }^{-}$and $\left(\mathrm{NH}_{4}\right)_{2} \mathrm{SO}_{4}$ as a source of $\mathrm{NH}_{4}^{+}$. The nutrient solution was completed daily to maintain its level at $2-3 \mathrm{~cm}$ above the surface of the vermiculite, resulting in a volume of $1,8 \mathrm{~L}$ per pot. The flooded condition was maintained for 5 days. Nonflooded controls were set up simultaneously, and supplied with full strength $\mathrm{N}$-free nutrient solution $(200 \mathrm{~mL})$ given on initiating treatments and on the third day of the experiment. Water was supplied as necessary.

For each treatment 3 replicates were used, each pot with 2 plants representing a replicate. The treatments were arranged in a completely randomized design. Data were subject to an analysis of variance and when significant the means compared by Duncan's Multiple Range test at the $5 \%$ probability level. 
Xylem bleeding sap was collected according to McClure and Israel (1979). The separation and analysis of amino acids in the xylem sap was carried out by reverse-phase HPLC using OPA amino acid derivatives, as described previously (Puiatti and Sodek, 1999). In view of the small amounts of sap available, total amino acid content of the sap was estimated from the recovery of amino acids after HPLC analysis. Ureides were determined by the method of Vogels and Van Der Drift (1970).

The concentration of $\mathrm{O}_{2}$ in the nutrient solution was measured using a portable oxygen meter (JENWAY, model 9071).

\section{RESULTS}

Flooding the nodulated root system of soybean with nutrient solutions containing different sources of $\mathrm{N}$ resulted in the fall of oxygen concentration in the solution from approximately $6.7 \mathrm{mg} \mathrm{O} \mathrm{O}_{2} \cdot \mathrm{L}^{-1}$ to $0.7 \mathrm{mg} . \mathrm{L}^{-1}$ within the first day, and thereafter to near $0.4 \mathrm{mg} . \mathrm{L}^{-1}$ over the 5 days of the experiment (data not shown). This indicates that hypoxic conditions prevailed during the flooding treatment. Little change in the solution $\mathrm{pH}$ took place during the 5-day treatment, and despite the daily completion of the solution level with nutrient solution containing the $\mathrm{N}$ source at $5 \mathrm{mM}$, no accumulation of $\mathrm{NO}_{3}{ }^{-}$and/or $\mathrm{NH}_{4}{ }^{+}$was observed (Thomas and Sodek, 2005).

Analysis for total free amino acids of the xylem sap over the 5-day experimental period revealed increases for all flooding treatments containing a $\mathrm{N}$ source (table 1). The largest increases were recorded when $\mathrm{NH}_{4}^{+}$was present during flooding. When plants were flooded with $\mathrm{NO}_{3}{ }^{-}$these values were significantly lower than for $\mathrm{NH}_{4}^{+}$on any day but higher than the $\mathrm{N}$-free control. The levels observed for $\mathrm{NH}_{4} \mathrm{NO}_{3}$ were intermediate to those of either $\mathrm{NO}_{3}{ }^{-}$or $\mathrm{NH}_{4}{ }^{+}$ alone. The non-flooded controls presented the same more or less constant low levels as the flooded $\mathrm{N}$-free control. Although some variation was observed over the 5 days of flooding, no specific pattern emerged and where increases over the initial value were recorded these occurred mainly within the first or second days of flooding.

The ureide content of the xylem sap (table 2) dropped to minimal values within the first day of flooding and in general remained at these low levels over the remainder of the 5-day experimental period. Some sign of recovery of xylem ureides was observed on the fourth and fifth days of flooding, but only for the $\mathrm{N}$-free control. The ureide content of the non-flooded controls on the other hand remained high throughout the experiment.
Table 1. Amino acid content of the xylem sap of symbiotic soybean during flooding of the root system with nutrient solution containing different sources of N. Plants at the V6-7 stage flooded with nutrient solutions containing no $\mathrm{N}(-\mathrm{N})$, $\mathrm{NO}_{3}{ }^{-}, \mathrm{NH}_{4}{ }^{+}$and $\mathrm{NH}_{4} \mathrm{NO}_{3}$. NF: non-flooded control.

\begin{tabular}{lccccccc}
\hline & \multicolumn{7}{c}{ Days after flooding } \\
\cline { 2 - 8 } Flooded & 0 & 1 & \multicolumn{7}{c}{2} & 3 & 4 & 5 \\
\hline & --1.4 & $1.4 \mathrm{c}^{*}$ & $1.6 \mathrm{c}$ & $0.9 \mathrm{c}$ & $1.2 \mathrm{c}$ & $1.2 \mathrm{c}$ \\
$\mathrm{NF}$ & -- & $1.4 \mathrm{c}$ & $1.4 \mathrm{c}$ & $1.0 \mathrm{c}$ & $0.9 \mathrm{c}$ & $0.6 \mathrm{c}$ \\
$-\mathrm{N}$ & -- & $1.9 \mathrm{c}$ & $3.2 \mathrm{bc}$ & $5.5 \mathrm{~b}$ & $2.9 \mathrm{~b}$ & $3.8 \mathrm{~b}$ \\
$\mathrm{NO}_{3}^{-}$ & -- & $6.6 \mathrm{a}$ & $7.6 \mathrm{a}$ & $7.8 \mathrm{a}$ & $5.4 \mathrm{a}$ & $6.1 \mathrm{a}$ \\
$\mathrm{NH}_{4}^{+}$ & - & $4.2 \mathrm{~b}$ & $4.6 \mathrm{~b}$ & $6.9 \mathrm{ab}$ & $4.8 \mathrm{a}$ & $4.7 \mathrm{~b}$ \\
$\mathrm{NH}_{4} \mathrm{NO}_{3}$ & -- & &
\end{tabular}

* Means followed by different letters (within columns) are significantly different by Duncan's Multiple Range test $(\mathrm{P} \leq 0,05)$

Table 2. Ureide content of the xylem sap of symbiotic soybean during flooding of the root system with nutrient solution containing different sources of N. Plants at the V6-7 stage flooded with nutrient solutions containing no $\mathrm{N}(-\mathrm{N}), \mathrm{NO}_{3}^{-}$, $\mathrm{NH}_{4}{ }^{+}$and $\mathrm{NH}_{4} \mathrm{NO}_{3}$. NF: non-flooded control.

\begin{tabular}{lcccccc}
\hline & \multicolumn{7}{c}{ Days after flooding } \\
\cline { 2 - 7 } Flooded & 0 & 1 & 2 & 3 & 4 & 5 \\
\hline & -2.8 & $3,0 \mathrm{a}^{*}$ & $3,1 \mathrm{a}$ & $2,3 \mathrm{a}$ & $1,9 \mathrm{a}$ & $2,3 \mathrm{a}$ \\
$\mathrm{NF}$ & -- & $0,1 \mathrm{~b}$ & $0,1 \mathrm{~b}$ & $0,1 \mathrm{~b}$ & $0,6 \mathrm{~b}$ & $0,6 \mathrm{~b}$ \\
$-\mathrm{N}$ & -- & $0,1 \mathrm{~b}$ & $0,1 \mathrm{~b}$ & $0,2 \mathrm{~b}$ & $0,2 \mathrm{c}$ & $0,1 \mathrm{c}$ \\
$\mathrm{NO}_{3}^{-}$ & -- & $0,1 \mathrm{~b}$ & $0,1 \mathrm{~b}$ & $0,1 \mathrm{~b}$ & $0,1 \mathrm{c}$ & $0,1 \mathrm{c}$ \\
$\mathrm{NH}_{4}^{+}$ & -- & $0,1 \mathrm{~b}$ & $0,1 \mathrm{~b}$ & $0,1 \mathrm{~b}$ & $0,1 \mathrm{c}$ & $0,1 \mathrm{c}$ \\
$\mathrm{NH}_{4} \mathrm{NO}_{3}$ & - &
\end{tabular}

* Means followed by different letters (within columns) are significantly different by Duncan's Multiple Range test $(\mathrm{P} \leq 0,05)$

In terms of individual amino acids of the xylem sap (figure 1), several responded strongly to the treatments imposed. Irrespective of the source of $\mathrm{N}$, alanine predominated in the xylem sap in all flooding treatments over at least the first 3 days, despite being one of the least important amino acids at the beginning of the experiment. However, the relative importance of alanine during hypoxia, as well as the period over which this amino acid predominated the xylem sap amino acids, showed some variation depending on the $\mathrm{N}$ source. The highest levels were found when $\mathrm{NH}_{4}{ }^{+}$was the source of $\mathrm{N}$, where values between 55 and $70 \%$ were recorded and these high values prevailed throughout the period of hypoxia. When $\mathrm{NO}_{3}{ }^{-}$was the source of $\mathrm{N}$, alanine reached values of $44 \%$ but these values were not maintained towards the end of the 5-day treatment period, falling to little more than $20 \%$ by day 5 . The mixture of $\mathrm{NH}_{4}^{+}$and $\mathrm{NO}_{3}{ }^{-}$led to intermediate values where alanine reached values near $49 \%$ and these were maintained 
throughout the experimental period. In the absence of a $\mathrm{N}$ source ( $\mathrm{N}$-free treatment) alanine rose initially to $30 \%$ over the first 2 days but gradually declined thereafter to $4 \%$ by day 5. Such changes were in strong contrast to the controls (not flooded) where alanine in the xylem sap remained low at around $1 \%$ throughout the experiment.

The amino acid aspartate also responded very strongly to the flooding treatment, independent of the $\mathrm{N}$ source (figure 1). However, the response of aspartate was the opposite of that shown by alanine. In all treatments the initial level of aspartate dropped sharply from $45 \%$ to very low values on the first day, coinciding with the very sharp rise in alanine over the same time period. It then remained at these low values throughout the experiment. Aspartate also fell in the non-flooded control but much less so than in the treatments, stabilizing at around $25 \%$ after day 3 .

The relative level of asparagine in the xylem sap also showed some variation during flooding according to the $\mathrm{N}$ source present. In all flooded treatments an initial drop in asparagine was recorded on the first day followed by a gradual increase. The largest increase was observed when $\mathrm{NO}_{3}^{-}$was present where levels increased to $48 \%$ by day 5 (figure 1B). In the presence of $\mathrm{NH}_{4}{ }^{+}$and the $\mathrm{N}$ free treatment, this increase was more discrete and only sufficient to recover the initial levels at day 5 (figures $1 \mathrm{~A}$ and 1D). When both $\mathrm{NH}_{4}{ }^{+}$and $\mathrm{NO}_{3}{ }^{-}$were present the increase was intermediary, but became stationary between 25 and 30 $\%$ after day 3 (figure $1 \mathrm{C}$ ).

Other amino acids worthy of mention include glutamine. This amide, which represented $17 \%$ of the xylem sap amino acids at the beginning of the experiment, fell quite sharply in the $\mathrm{N}$-free and $\mathrm{NO}_{3}{ }^{-}$treatments but more slowly in the two treatments where $\mathrm{NH}_{4}{ }^{+}$was present. Serine (data not shown) increased in all treatments with flooding (from about $1 \%$ initially) but not to the same degree as alanine (reaching between 5 and $12 \%$ ). Gaba (data not shown) also produced small but transient increases in all treatments (from $2 \%$ to less than $10 \%$ ), this being permanent in the $\mathrm{N}$-free treatment (at near $10 \%$ ).

\section{DISCUSSION}

The presence of $\mathrm{NO}_{3}{ }^{-}$during a period of flooding is known to improve the tolerance of plants to this stress (Malavolta, 1954; Trought and Drew, 1981; Prioul and Guyot, 1985; Becanamwo and Purcell, 1999a,b). The beneficial effect of $\mathrm{NO}_{3}{ }^{-}$for soybean plants subjected to flooding, for the same experimental conditions as used in this investigation, has also been clearly demonstrated (Thomas and Sodek, 2005). In that study, dry matter accumulation was as high as the non-flooded control, although total accumulation of $\mathrm{N}$ in the shoot fell short of that of the control. $\mathrm{NH}_{4}^{+}$, on the other hand, showed absolutely no benefit, with a dry matter accumulation as low as the $\mathrm{N}$-free flooded control, although shoot $\mathrm{N}$ accumulation despite being lower than for the $\mathrm{NO}_{3}{ }^{-}$treatment was superior to the N-free control (Thomas and Sodek, 2005). Elevated levels of amino acids in the xylem sap (reported in more detail in this study) indicate extensive absorption and assimilation of $\mathrm{NH}_{4}{ }^{+}$in the roots. Furthermore, the production of alanine, the principal product of anaerobic $\mathrm{N}$ metabolism, is greatly enhanced in the presence of $\mathrm{NH}_{4}^{+}$, a phenomenon reported previously by Vanleberghe and colleagues (Vanlerberghe and Turpin, 1990; Vanlerberghe et al., 1991). The question arises as to why this apparently efficient assimilation of $\mathrm{NH}_{4}{ }^{+}$does not lead to dry matter accumulation under hypoxia above that seen with the $\mathrm{N}$-free treatment. $\mathrm{NO}_{3}{ }^{-}$, which is very efficient in this aspect, does not lead to such high levels of alanine and amino acids in the xylem sap. Possibly, the effect of $\mathrm{NH}_{4}^{+}$on $\mathrm{N}$ accumulation during flooding is anomalous, since the assimilation of $\mathrm{NH}_{4}^{+}$may be simply a means of avoiding its accumulation and consequent deleterious effects. The consumption of photosynthates under $\mathrm{NH}_{4}{ }^{+}$nutrition may be much greater than that required for assimilation and include that necessary to sustain the high energy costs should appreciable quantities of $\mathrm{NH}_{4}{ }^{+}$be pumped back out into the medium. This mechanism has been postulated by Britto et al. (2001) as part of a futile transmembrane $\mathrm{NH}_{4}^{+}$ cycling phenomenon to explain $\mathrm{NH}_{4}^{+}$toxicity in plants. This is an important point, since the demand for carbon skeletons alone would not explain the different response observed with $\mathrm{NO}_{3}{ }^{-}$, whose assimilation must pass through $\mathrm{NH}_{4}^{+}$, and consequently in our experiments $\mathrm{NO}_{3}{ }^{-}$would in fact exert a greater demand for carbon skeletons than $\mathrm{NH}_{4}^{+}$since it is apparently assimilated in greater quantities, as judged by the accumulation of $\mathrm{N}$ in the shoot reported previously (Thomas and Sodek, 2005). The high levels of amino acids seen in the xylem may, therefore, simply reflect a detoxification mechanism for $\mathrm{NH}_{4}^{+}$. The high energy costs of $\mathrm{NH}_{4}^{+}$ detoxification may explain the lack of photosynthates for dry mass accumulation, under conditions where photosynthate production is probably limited in view of the negative effect of flooding stress on photosynthesis (Linkemer et al., 1998; Oosterhuis et al., 1990). Evidently, the greater accumulation of $\mathrm{N}$ derived from $\mathrm{NO}_{3}{ }^{-}$reflects a more efficient metabolism of $\mathrm{N}$ than that seen with $\mathrm{NH}_{4}^{+}$as $\mathrm{N}$ source. The xylem sap 

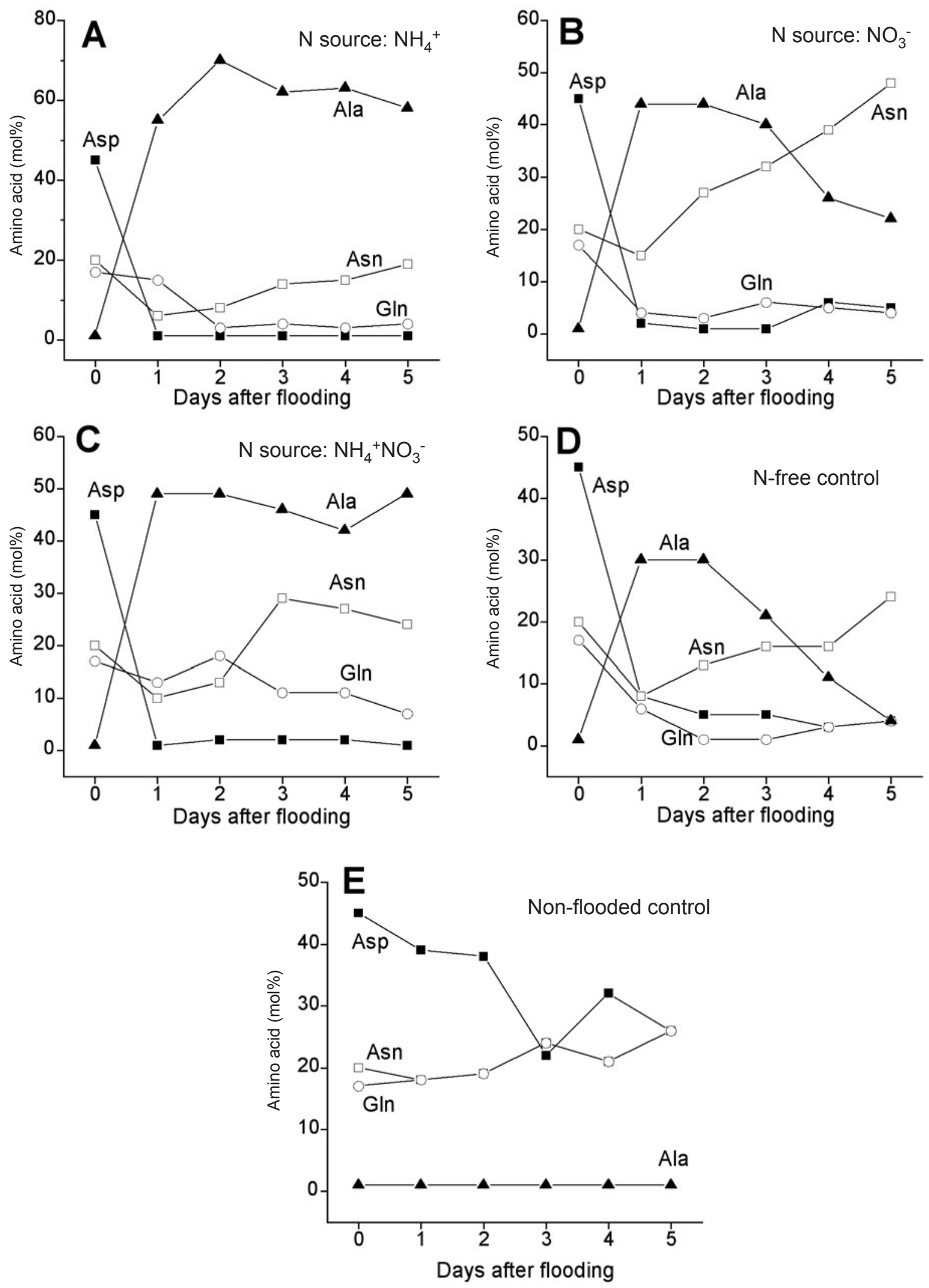

Figure 1. Variations of the principal amino acids of the xylem bleeding sap of soybean plants during the flooding of the root system for 5 days with nutrient solution containing $\mathrm{NH}_{4}^{+}, \mathrm{NO}_{3}^{-}, \mathrm{NH}_{4} \mathrm{NO}_{3}$ or $\mathrm{N}$-free. The non-flooded control is included for

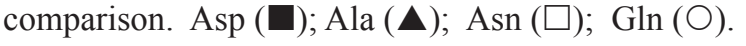


amino acid data also indicate active $\mathrm{NO}_{3}{ }^{-}$assimilation when $\mathrm{NO}_{3}{ }^{-}$is present under the flooding conditions used here. The large increase in asparagine in the xylem sap during flooding in the presence of $\mathrm{NO}_{3}{ }^{-}$is characteristic of soybean dependent on $\mathrm{NO}_{3}{ }^{-}$assimilation and seen under normoxia when nodulated plants are fed $\mathrm{NO}_{3}{ }^{-}$as they switch from $\mathrm{N}_{2}$ fixation to $\mathrm{NO}_{3}{ }^{-}$assimilation (Lima and Sodek, 2003). The efficient assimilation of nitrate during flooding observed here is consistent with the conclusion reached by Allegre et al. (2004), that increased nitrate reductase activity of the roots underlies the beneficial effects of nitrate on tomato plants subjected to flooding.

The dramatic increases in alanine of the xylem sap under flooding treatments reflect synthesis of alanine in roots during hypoxia (Sousa and Sodek, 2003). However, it is apparent that alanine synthesis does not depend solely on mineral $\mathrm{N}$ assimilation. Alanine was synthesized in the $\mathrm{N}-$ free plants under hypoxia, although this was certainly more restricted than that seen when a $\mathrm{N}$ source was present. $\mathrm{N}_{2}$ fixation is seriously impaired under these conditions, as seen by the reduction of xylem ureide levels to trace amounts. This raises the question as to the source of $\mathrm{N}$ for alanine synthesis in the N-free treatment. Since the plants used were symbiotically-dependent plants, there would be no endogenous $\mathrm{NO}_{3}{ }^{-}$that could be mobilized for this purpose. Nor is it likely that endogenous amino acid pools or protein are the source since these $\mathrm{N}$ fractions increase in the roots during the flooding stress, not only in $\mathrm{NO}_{3}^{-}$-fed plants (Sousa and Sodek, 2002b) but in symbiotic plants also (Brito and Sodek, unpublished data) where $\mathrm{N}_{2}$ fixation is impaired by hypoxia (Lima and Sodek, 2003). There is, however, good evidence that the immediate source of $\mathrm{N}$ for alanine synthesis is aspartic acid (see discussion below) whether a $\mathrm{N}$ source is present or not. In spite of the prominence of alanine synthesis during hypoxia, its physiological role is not clear, especially since the reaction does not regenerate $\mathrm{NAD}^{+}$in contrast to the fermentation reactions involving pyruvate (ethanol and lactate formation). Nevertheless, the fact that alanine is not toxic to the cell and contributes to $\mathrm{pH}$ regulation are in themselves important characteristics for tolerance of hypoxia (Reggiani et al., 1988; Sousa and Sodek, 2002a). However, a role in fermentation cannot be ruled out since reactions that regenerate $\mathrm{NAD}^{+}$(such as GOGAT) may be associated with the supply of $\mathrm{N}$ for alanine formation (Sousa and Sodek, 2003).

Besides alanine, some important changes in other amino acids occurred in the xylem sap of the flooded plants. First, there is a very clear inverse relationship between alanine and aspartic acid. This phenomenon has been reported before with non-nodulated plants and interpreted as indicating that aspartate is a source of $\mathrm{N}$ for alanine synthesis (Sousa and Sodek, 2003). Nevertheless, the inverse relationship between aspartate and alanine is particularly evident here for the symbiotic plants, in view of the high initial level of aspartate. Indeed, this level is unusually high compared to that generally found (Puiatti and Sodek, 1999; Lima and Sodek, 2003) and may be due to excessive watering (unpublished data); in this respect, it is noteworthy that high aspartate is characteristic of symbiotic plants transferred to aerated hydroponics (Lima and Sodek, 2003). Consequently, its gradual decline in the non-flooded controls seen here may be simply a reflection of less zealous watering. The fact that alanine declined quite sharply in the $\mathrm{N}$-free treatment after the initial increase, in contrast to the $\mathrm{NO}_{3}{ }^{-}$treatment which declined more slowly or the $\mathrm{NH}_{4}{ }^{+}$treatment which did not decline at all, may reflect the lack of assimilatory processes to replenish the aspartate consumed. The hypothesis that aspartate is a precursor of alanine synthesis is also supported by the fact that when symbiotic plants are flooded and aerated (aerated hydroponics), where alanine is not formed because the roots do not become hypoxic, aspartate levels in the xylem increase to high levels and do not fall (Lima and Sodek, 2003). Vanlerberghe et al. (1991) also concluded that aspartate was the precursor of alanine during anaerobiosis of Selenastrum in the absence of an external N source.

The other xylem amino acid that responds strongly to treatment is glutamine. This amide is reduced to low levels under flooded conditions, a phenomenon attributed to impaired $\mathrm{N}_{2}$ fixation (Amarante and Sodek, 2006). Indeed, xylem ureides, known to be specific products of $\mathrm{N}_{2}$ fixation (McClure et al, 1980; Herridge and Peoples, 1990) parallel this decline. The presence of a $\mathrm{N}$ source had little or no effect on this phenomenon, except in the case of $\mathrm{NH}_{4} \mathrm{NO}_{3}$ where the decline was less pronounced. Nevertheless, it is unlikely that the slower decline of glutamine with $\mathrm{NH}_{4} \mathrm{NO}_{3}$ was due to $\mathrm{N}_{2}$ fixation and is more likely to involve other sources.

Despite $\mathrm{NH}_{4}{ }^{+}$being the predominant form of mineral $\mathrm{N}$ in flooded soils (Marschner, 1995), its presence in the medium brings no benefit to tolerance of soybean to hypoxia, in contrast to $\mathrm{NO}_{3}{ }^{-}$(Thomas and Sodek, 2005). Although both forms of $\mathrm{N}$ appear to be assimilated under the flooding conditions used, $\mathrm{NH}_{4}{ }^{+}$nutrition leads to a less efficient metabolism of $\mathrm{N}$ possibly resulting from energy metabolism being directed towards $\mathrm{NH}_{4}{ }^{+}$detoxification. 
Acknowledgements: We thank CNPq for financial support and CAPES for the fellowship awarded to A.L.T.

\section{REFERENCES}

Allègre A, Silvestre J, Morard P, Kallerhoff J, Pinelli E (2004) Nitrate reductase regulation in tomato roots by exogenous nitrate: a possible role in tolerance to long-term root anoxia. J. Exp. Bot. 55:2625-2634.

Amarante L do, Sodek L (2006) Waterlogging effect on xylem sap glutamine of nodulated soybean. Biol. Plant. 50: 405-410.

Armstrong W, Brändle R, Jackson MB (1994) Mechanisms of flood tolerance in plants. Acta Bot. Neerl. 43:307-358.

Bacanamwo M, Purcell LC (1999a) Soybean root morphological and anatomical traits associated with acclimation to flooding. Crop Sci. 39:143-149.

Bacanamwo M, Purcell LC (1999b) Soybean dry matter and $\mathrm{N}$ accumulation responses to flooding stress, $\mathrm{N}$ sources and hypoxia. J. Exp. Bot. 50:689-696.

Blumenthal JM, Russelle MP, Vance CP (1997) Nitrogenase activity is affected by reduced partial pressures of $\mathrm{N}_{2}$ and $\mathrm{NO}_{3}{ }^{-}$. Plant Physiol. 114:1405-1412.

Britto DT, Siddiqi MY, Glass ADM, Kronzucker HJ (2001) Futile transmembrane $\mathrm{NH}_{4}^{+}$cycling: A cellular hypothesis to explain ammonium toxicity in plants. Proc. Natl. Acad. Sci. USA 98:4255-4258.

Costa JA, Marchezan E (1982) Características dos estádios de desenvolvimento da soja. Fundação Cargill, Campinas, $32 \mathrm{p}$.

Drew MC, He C, Morgan PW (2000) Programmed cell death and aerenchyma formation in roots. Trends Plant Sci. 5: 123-127.

Herridge DF, Peoples MB (1990) Ureide assay for measuring nitrogen fixation by nodulated soybean calibrated by ${ }^{15} \mathrm{~N}$ methods. Plant Physiol. 93:495-503.

Hoagland DR, Arnon DI (1950) The water culture method for growing plants without soil. Calif. Agric. Exp. Sta. Bull., Circular 347

Howitt SM, Udvardi MK (2000) Structure, function and regulation of ammonium transporters in plants. Biochim. Biophys. Acta 1465:152-170.

Kaiser MW, Huber SC (2001) Post-translational regulation of nitrate reductase: mechanism, physiological relevance and environmental triggers. J. Exp. Bot. 52:1981-1989.

Liesack W, Schnell S, Revsbech NP (2000) Microbiology of flooded rice paddies. FEMS Microbiol. Rev. 24:625-645.

Lima JD, Sodek L (2003) N-stress alters aspartate and asparagine levels of xylem sap in soybean Plant Sci. 165:649-656.

Linkemer G, Board JE, Musgrave ME (1998) Waterlogging effects on growth and yield components in late-planted soybean. Crop Sci. 38:1576-1584.

Magalhães JR, Silva FLIM, Salgado I, Ferrarese-Filho O, Rockel P, Kaiser WM (2002). Nitric oxide and nitrate reductase in higher plants. Physiol. Mol. Biol. Plants 8:11-17.

Malavolta, E. (1954) Studies on the nitrogenous nutrition of rice. Plant Physiol. 29:98-99.
Marschner, H. (1995) Mineral nutrition of higher plants. Academic Press, London.

McClure PR, Israel DW, Volk RJ (1980) Evaluation of the relative ureide content of xylem sap as an indicator of $\mathrm{N}_{2}$ fixation in soybeans. Plant Physiol. 66:720-725.

McClure PR, Israel DW (1979) Transport of nitrogen in the xylem of soybean plants. Plant Physiol. 64:411-416.

Oosterhuis DM, Scott HD, Hampton RE, Wullschleger SD (1990) Physiological responses of two soybean [Glycine $\max (\mathrm{L}$.) Merr] cultivars to short-term flooding. Environ. Exp. Bot. 30:85-92.

Prioul JL, Guyot C (1985) Role of oxygen transport and nitrate metabolism in the adaptation of wheat plants to root anaerobiosis. Physiol. Veg. 23:175-185.

Puiatti M, Sodek L (1999) Waterlogging affects nitrogen transport in the xylem of soybean. Plant Physiol. Biochem. 37: 767-773.

Reggiani R, Cantú CA, Brambilla I, Bertani A (1988) Accumulation and interconversion of amino acids in rice roots under anoxia. Plant Cell Physiol. 29:981-987.

Sousa CAF de, Sodek L (2002a). The metabolic response of plants to oxygen deficiency. Braz. J. Plant Physiol. 14:8394.

Sousa CAF de, Sodek L (2002b) Metabolic changes in soybean plants in response to waterlogging in the presence of nitrate. Physiol. Mol. Biol. Plants. 8:97-104.

Sousa CAF de, Sodek L (2003) Alanine metabolism and alanine aminotransferase activity in soybean (Glycine max) during hypoxia of the root system and subsequent return to normoxia. Environ. Exp. Bot. 50:1-8.

Sousa S, Camargo FAO, Vahl LC (2000) Solos Alagados. In: Meurer EJ (ed), Fundamentos de Química de Solo, pp.127149. Gênesis, Porto Alegre-RS.

Thomas AL, Sodek L (2005) Development of the nodulated soybean plant after flooding of the root system with different sources of nitrogen. Braz. J. Plant Physiol. 17:291-297.

Thomas AL, Guerreiro SMC, Sodek L (2005) Aerenchyma formation and recovery from hypoxia of the flooded root system of nodulated soybean. Ann. Bot. 96:1191-1198.

Trought MCT, Drew MC (1981) Alleviation of injury to young wheat plants in anaerobic solution cultures in relation to the supply of nitrate and other inorganic nutrients. J. Exp. Bot. 32:509-522.

Vanlerberghe GC, Turpin DH (1990) Anaerobic metabolism in the N-limited green alga Selenastrum minutum: II. Assimilation of ammonium by anaerobiose cells. Plant Physiol. 94:1124-1130.

Vanlerberghe GC, Joy KW, Turpin DH (1991) Anaerobic metabolism in the N-limited green alga Selenastrum minutum: III. Alanine is the product of anaerobic ammonium assimilation. Plant Physiol. 95:655-658.

Vogels GD, Van Der Drift C (1970) Differential analysis of glyoxylate derivatives. Anal. Biochem. 33:143-157.

Wirén N Von, Gazzarrini S, Gojon A, Frommer WB (2000) The molecular physiology of ammonium uptake and retrieval. Curr. Opin. Plant Biol. 3:254-261. 